\title{
A patient's diary: episode 17 - Eyes on the blink
}

I don't know why it is but life these days seems to bring one health problem after another. My pancreas has at last settled down (thanks to those excellent little enzyme tablets from the health food shop) and I thought I would be able to emerge from the shadow of the valley of Illness onto the sunlit uplands of Health. But alas, it was not to be. Last night the Eye Trouble started. At first I thought I was looking at a couple of black spots on the white bedroom wall (just between the wardrobe and the Canaletto). But then, when I moved my eyes, the spots moved as well! I switched my gaze to another part of the wall and, to my dismay, the black spots arrived there too, a fraction of a second later. They were following me round the room just like that picture of the Laughing Cavalier. I tried cleaning my glasses but that made no difference; I gave my eyes a vigorous rub which made them feel rather sore; but when I opened them again, the horrid spots were still there, dancing mischievously about. Well, naturally I feared the worst. A haemorrhage or a semidetached retina, tapping along with a white stick or maybe a guide dog, and l've never really got on with dogs.

I woke early, hoping the spots would have disappeared in the night, but no, they were still there so I telephoned the surgery as soon as they opened at 9 a.m. Of course, I had the usual difficulty with engaged tones and 'if you know the extension you require press so and so; otherwise please hold for a receptionist'. So I held on and prayed that it would not be Mrs Flagg. But it was; and she recognised my voice instantly. Well, I know I am quite a regular customer but there was really no need for her to say, 'and what is it this time?' in that world-weary tone of voice. Who does she think she is, Lady Bracknell? But when she heard I had a probable detached or semidetached retina she became somewhat more sympathetic and gave me an appointment for the afternoon surgery without any further interrogation.
The next 6 hours were extremely trying, not to say worrying. The little black spots multiplied further and one of them became as big as a bluebottle. Well, an ant anyway. My appointment with $\mathrm{Dr}$ Teacher was for 3.30 p.m. but I arrive at the surgery on the stroke of 3 . Sometimes there is an unexpected gap in the first half hour because someone else is late or has felt better and decided not to come. But this afternoon everybody seemed to be on time except $\mathrm{Dr}$ Teacher who arrived looking rather flustered at 3.25 p.m.

Mrs Flagg came and explained to us patients (some of whom were getting restless) that he had been on an urgent house call to someone who was 'seriously ill.' She managed to imply in her tone of voice that none of us were really ill at all and had better not complain about the delay. The effect was rather spoiled by $\mathrm{Dr}$ Teacher popping his head out of his room and saying, 'Yet another totally unnecessary so-called emergency visit, Mrs Flagg. If it happens again, Mrs Snettisham is going off the list.' Mrs Flagg made soothing noises and a few minutes later she was seen going into Dr Teacher's room with an early cup of tea and a piece of chocolate cake. Meanwhile, my spots had begun to whiz and whirligig all over the place like those demented insects that skate over the surface of a pond and my vision was getting more and more cloudy.

I wondered if $\mathrm{Dr}$ Teacher would be in time to save my sight. I imagined him exclaiming in dismay when he looked into my eyes and saying, Oh Norman, if only you had come this morning or even half an hour ago. If only Mrs Snettisham had not delayed me with her frivolous request for an emergency visit. She shall be struck off the list at once. No, no I would remonstrate gently from out of the darkness which by now had enfolded me forever. Let her stay, Dr Teacher. She could not have known.

The time must have passed quite quickly while I was in this reverie because I woke with a start to find people were prodding me and saying: 'Go in. It's your turn.' I was relieved to find that I could still see well enough to find my way into the consulting room. I told my story to $\mathrm{Dr}$ Teacher who seemed not at all worried. 'Have you had any black curtains coming down, or going up?' he asked casually. Well no I couldn't say I had seen any curtains, just lots of black spots and insects. 'It's a well-known phenomenon, Norman,' he said, 'and quite harmless. You probably have a partial detachment of the vitreous jelly in front of the retina. But it's of no consequence. The black spots are little dead cells shed in the process. Because they look like flies and they move about they are called Musky Volitansky, Latin you know.'

Well, it sounded more like Russian to me, but I wasn't going to argue. 'Aren't you going to look in my eyes?' I asked, 'just in case there is a haemorrhage or a detached retina? Dr Teacher gave a deep sigh and started rummaging in his desk drawers for his ophthalmoscope, which they don't use very often as it's too complicated for the average GP. He found one in the end but the battery was flat or something so he called in young doctor Sally, who had a nice new one in a smart leather case with her name on it. She asked $\mathrm{Dr}$ Teacher to draw the curtains. Then she put her head very close to mine and shone an amazingly powerful light into my left eye. I was totally blinded at first but felt no pain. I think she must have some sort of laser in there that she used to burn up the dead cells or whatever they were. Then she gave the other eye the same treatment. When she had finished my eyes were watering profusely but the black spots seemed to have gone. Dr Sally reassured me that all was well and that there was no sign of any haemorrhage or detachment. But perhaps I should see the eye specialist at the hospital just to make sure.

She was really very nice about it with none of the deep personal questions one tends to get from her at times. Dr Teacher 
said they would phone the Eye Clinic for an urgent appointment. But I was no longer bothered. It was as if the scales had fallen from my eyes (metaphorically of course). There are still a few flies about but not nearly so many and I shall not go blind. I think next week I might ask her to have a go at my ears with that light of hers. It might get rid of those popping noises I have been getting lately.

We are grateful to John Salinsky for these extracts from Norman Gland's diary.

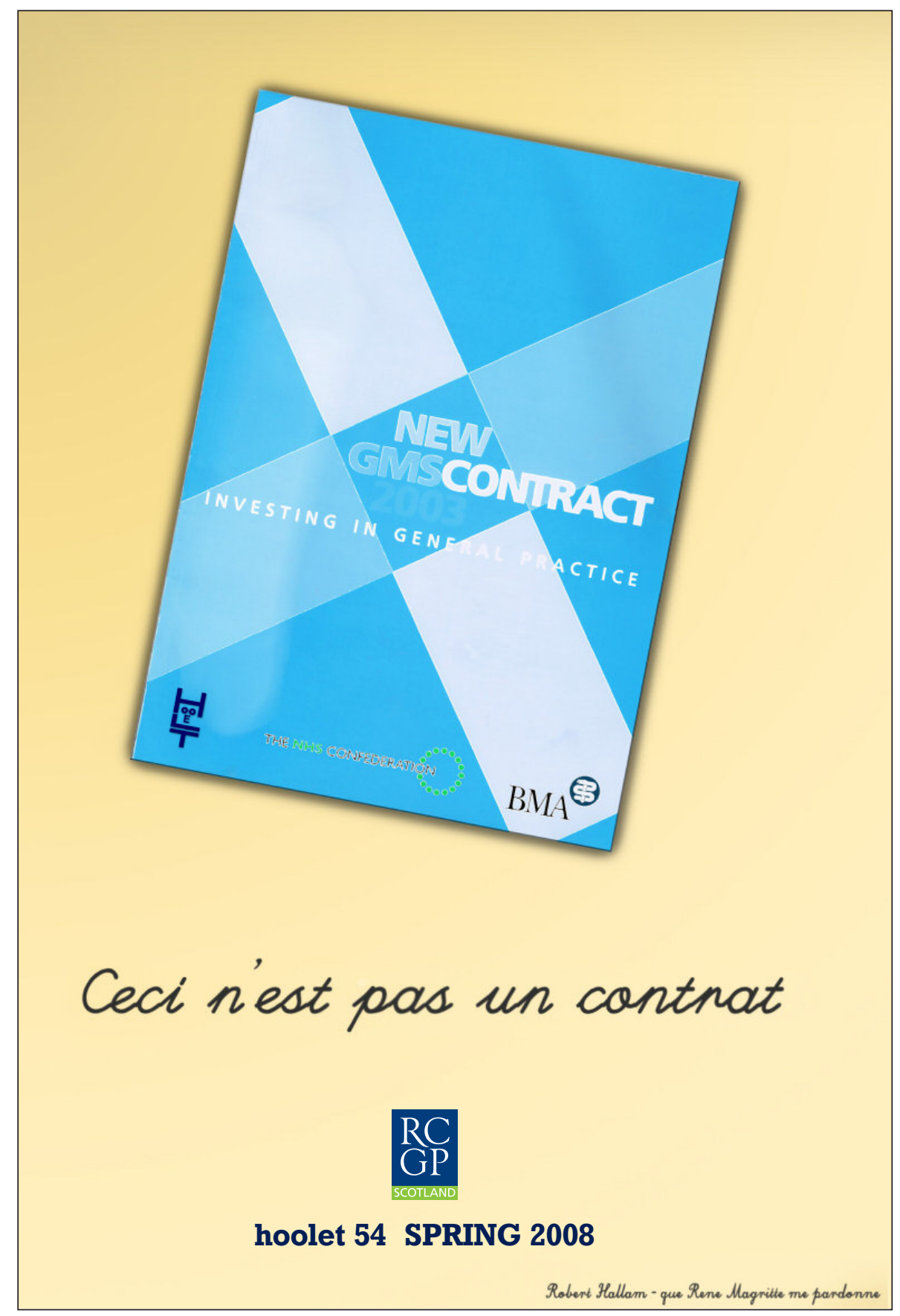

Extended opening hours is popular all across the UK. Herewith the springtime cover of RCGP Scotland's splendid organ, hoolet. With thanks to hoolet's Editor, Chris Johnstone. 